\title{
ANICTOMYIA, A NEW MYRMECOPHILOUS PHORID FROM THE PHILIPPINES
}

\section{By Charles T. Brues}

Among the extensive collections of ants obtained by Dr. J. W. Chapman on the island of Negros in the Philippines are several specimens of a most remarkable species of Phoridæ which he found living with ants of the genus Anictus. Dr. Chapman has very kindly placed these specimens at my disposal with the suggestion that I describe the species, which proves to be a wholly unknown form, which must form the type of a new subgenus.

In the very recent classification of this family by Schmitz, the new ænictophile falls in the genus Diploneura, which Schmitz has divided into three subgenera, Diploneura sensu stricto, Tristœchia and Dohrniphora, but it differs from all of these by a very complete development of the dorsal macrochætæ on the thorax as well as by the excessive length of the bristles on the head and wings.

The following tabular arrangement will indicate the characteristics that serve to distinguish the several subgenera:

1. Hind tibiæ with two dorsal (extensor) lines formed of closely spaced and imbricated bristles, and between these with a series of minute well separated bristles; mesopleuræ bare above ...............................2 Hind tibiæ with only a single row of bristles forming a line of the dorsal surface, mesopleuræ hairy above

2. Fourth longitudinal vein sinuous, the base curved upwards and the apex downwards Diploneura, s. str. Fourth longitudinal vein straight, not distinctly sinuous, nor curved at base of apex.

Tristoechia 
3. Mesonotum completely bristled; with a median row of four macrochætæ; four achrostichals, three or four dorsocentrals and six marginal scutellar bristles; the macrochætæ all as long or longer than the mesonotum; base of third vein bearing one very long bristle Enictomyia, subgen. nov.

Mesonotum minutely hairy, without macrochætæ except near lateral and posterior margins; base of third vein bare or with one or two very short bristles

Dohrinphora

Aenictomyia subgen. nov.

Although clearly related to Dohrniphora, the type of this subgenus exhibits several striking characters. The bristling of the entire body is unusually long as well as the cilia on the costal vein. The very complete and conspicuous chrtotaxy of the mesonotum is very unusual, as in practically all Phoridæ the median and anterior macrochætæ are completely suppressed, although those along the posterior and lateral margins are generally more or less well developed. The front is completely bristled; the proboscis geniculate and strongly chitinized; eyes hairy; palpi strongly bristled; cheeks each with three very strong macrochætæ; propleura hairy, with a large macrochæta; mesopleura hairy above; front tibia with a series of four small macrochætæ on dorsal surface; middle tibia with a strong basal pair; hind tibiæ without macrochætæ before apex; fourth wing-vein curved; seventh not distinct.

Type: Diploneura (Anictomyia) chapmani sp. nov.

Diploneura (Aenictomyia) chapmani sp. nov., Fig. 1.

Female: Length 1.2-1.5 mm.

Yellowish brown, the middle portion of the front, the mesonotum more or less, the tergites of the second and third abdominal segments and the apical one darker brown, the legs lighter, except the hind pair; wings hyaline with the heavy veins light brown. Front wider than long, the 
surface smooth, impunctate; the upper margin sharp and forming a slightly raised rim except at the sides; two closely approximated supra-antennal bristles directed upwards and backwards; lower transverse frontal row consisting of four equidistant bristles, the lateral ones well removed from the margin of the eye; middle row further
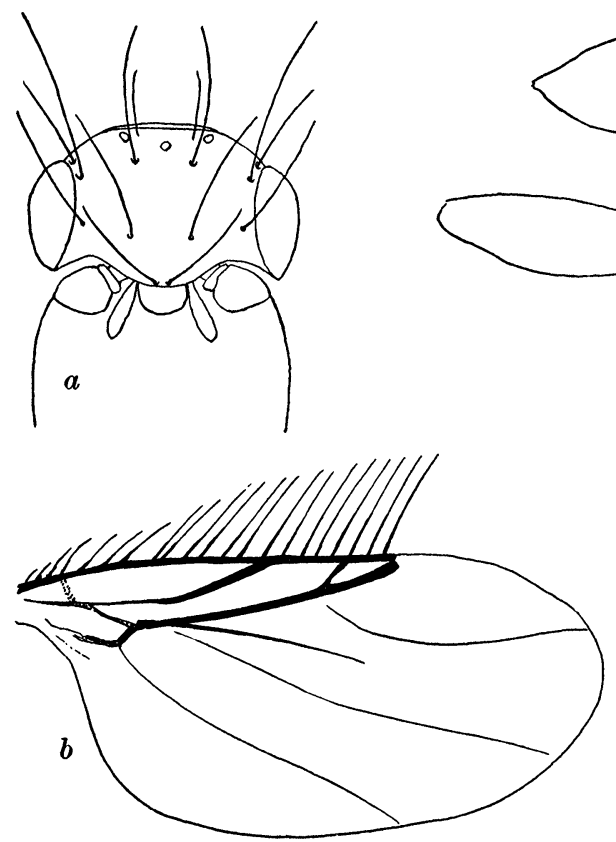

Fig. 1. Diploneura (AEnictomyia) chapmani sp. nov.

from the lower one than from the upper, of four equidistant bristles; upper or ocellar row close to the occipital margin; postocular cilia strong, especially above; cheeks each with three very large and strong bristles; bristles of palpi rather strong and densely placed. Proboscis beyond the basal angle about as long as the head-height, gently curved downwards to the tip. Antennæ small, oval; with a moderately long, weakly pubescent arista. Mesonotum smooth, highly polished, without any microscopic hairs be- 
tween the large macrochætæ; six scutellar bristles, the median ones much further from one another than the others so that there is a group of three on each side, the middle one of which is much longer than either the lateral or median one. Propleura sparsely hairy, with four small bristles at the base of the coxa and a large, erect one at the upper angle; mesopleura sparsely hairy on the upper half. Front tibia with a series of four moderately long bristles on the outer (extensor) edge, one at the basal third, one at middle and two between middle and apex. Middle tibia with a pair of long bristles near base (Fig. 1, c) and two short ones externally at tip. Hind tibia without long bristles. Abdomen very weakly chitinized; with a distinct large dorsal plate on the second and a small transverse plate on the second segment. Wings rather small, costa extending beyond the middle (Fig. 1, b), its cilia very long; third vein forked well before apex; base of third vein with one very long bristle near base; seventh vein not distinct.

Described from three specimens taken by Dr. J. W. Chapman with AEnictus martini Forel, at his summer camp in the mountains near Dumaguete, Negros Oriental, Philippine Islands. Dr. Chapman tells me that the Phorids ran along in the foray during the migration of the colony, making faster progress than the ants. 

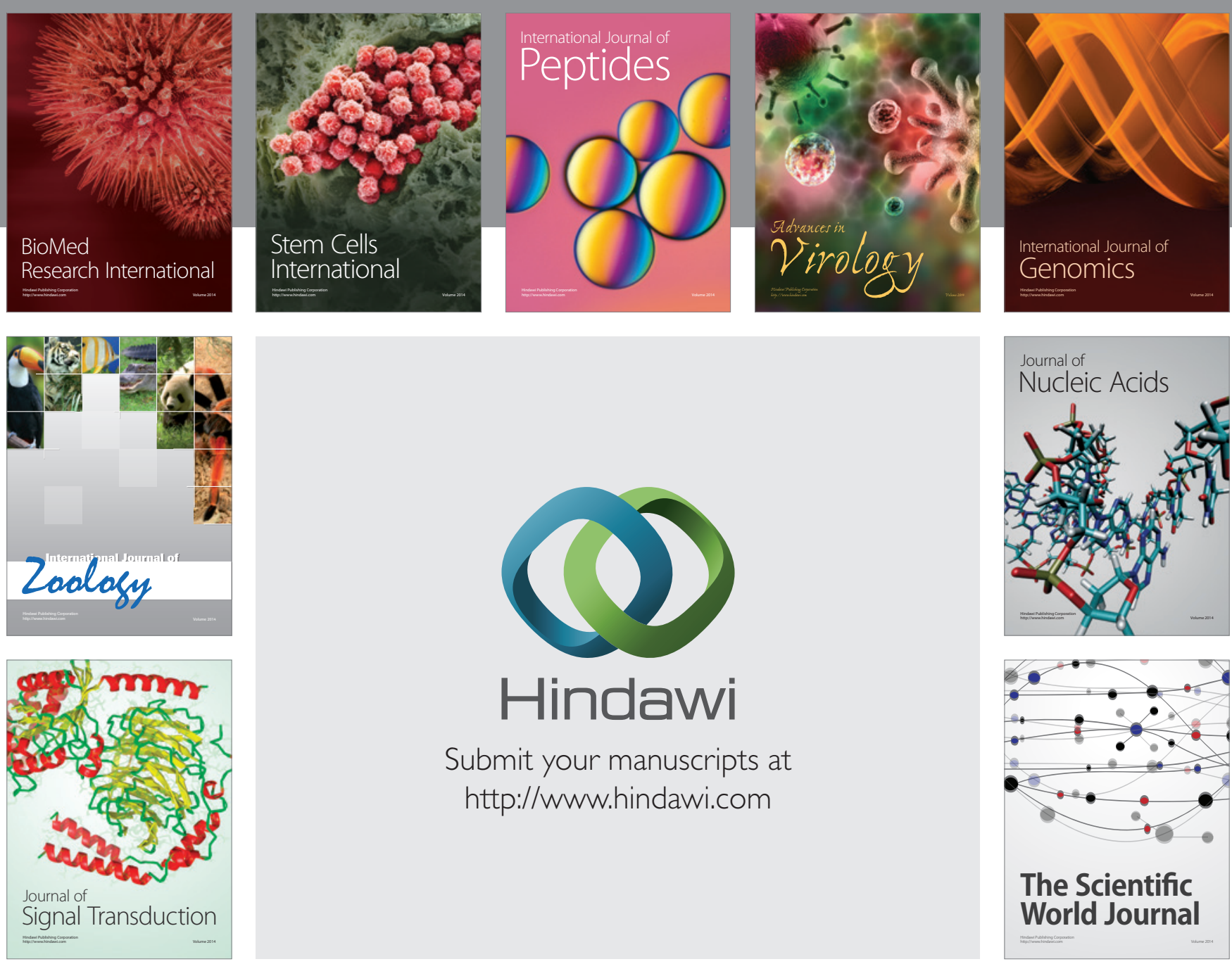

Submit your manuscripts at

http://www.hindawi.com
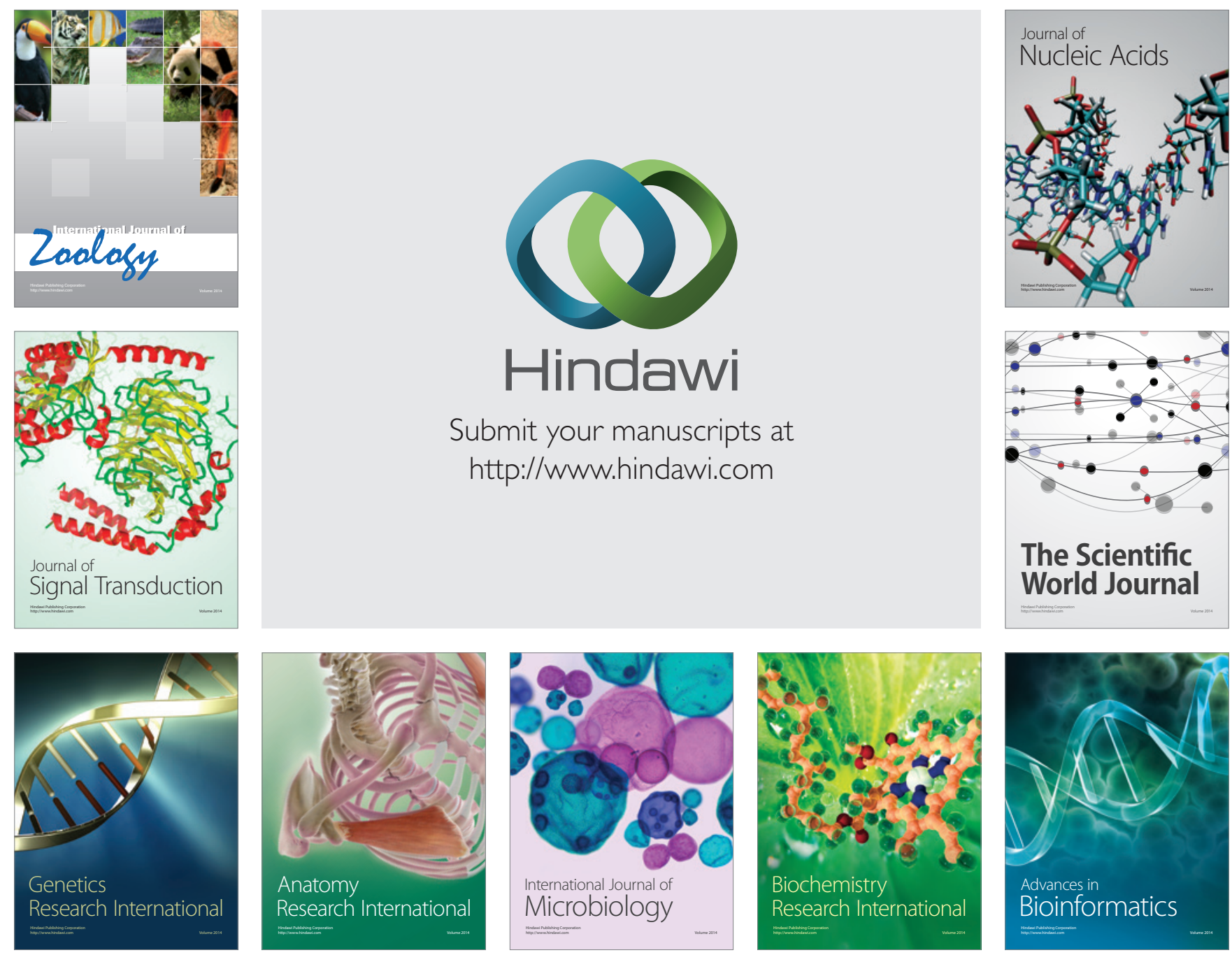

The Scientific World Journal
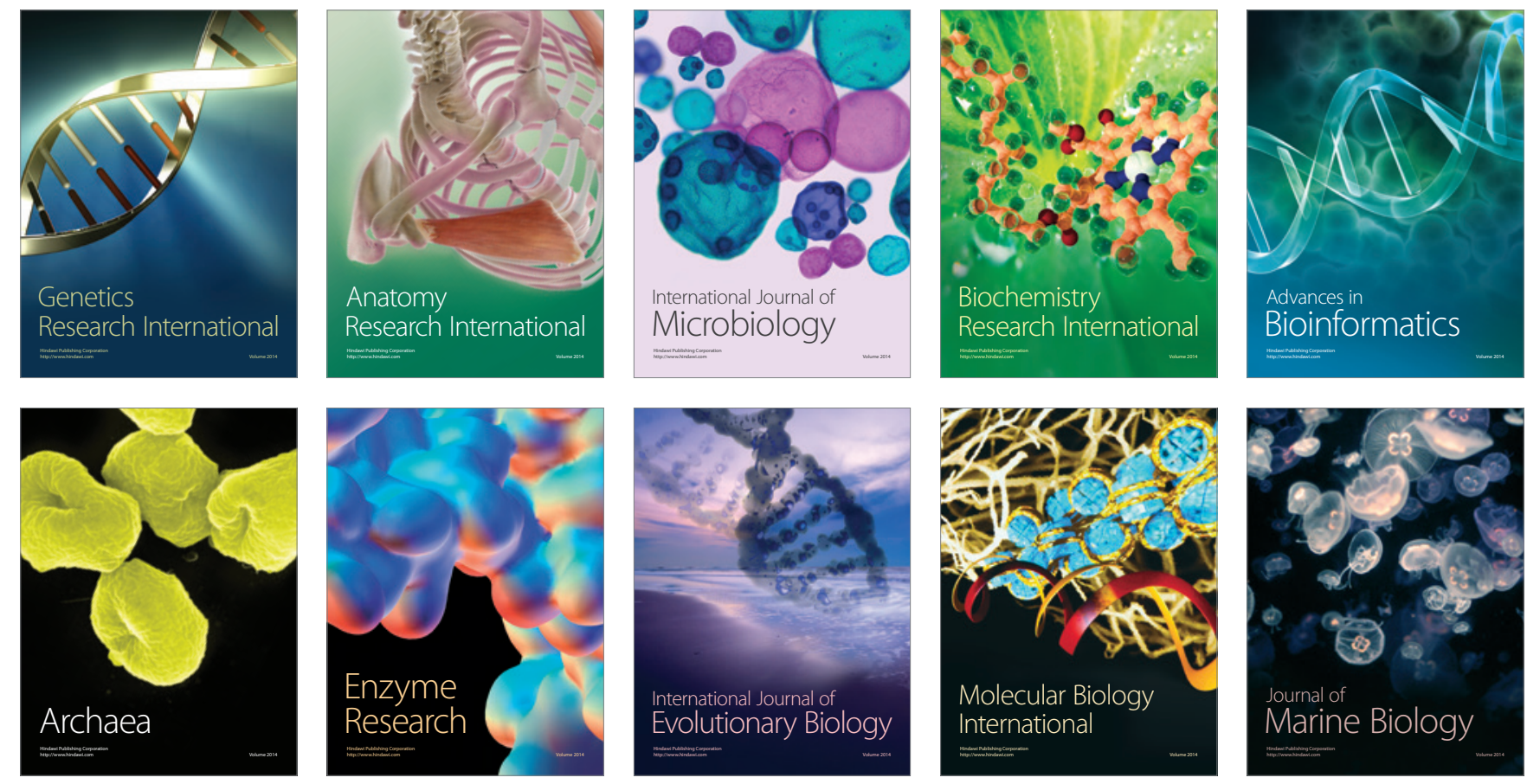